\title{
Association between G316A growth hormone polymorphism and economic traits in pigs
}

\author{
Danielle Assis de Faria ${ }^{1}$, Simone Eliza Facioni Guimarães ${ }^{1}$, Paulo Sávio Lopes ${ }^{1}$, Aldrin Vieira Pires ${ }^{2}$, \\ Samuel Rezende Paiva ${ }^{3}$, Bruna Pena Sollero ${ }^{1}$ and Amauri Arias Wenceslau ${ }^{4}$ \\ ${ }^{1}$ Departamento de Zootecnia, Universidade Federal de Viçosa, Viçosa, MG, Brazil. \\ ${ }^{2}$ Sistema FAESA de Ensino, Rod. Serafim Derenzi, Vitória, ES, Brazil. \\ ${ }^{3}$ Laboratório Genética Animal, Embrapa Recursos Genéticos e Biotecnologia, Brasilia, DF, Brazil. \\ ${ }^{4}$ Departamento de Ciências Agrárias, Universidade Estadual de Santa Cruz, Ilhéus, BA, Brazil.
}

\begin{abstract}
The association between G316A growth hormone polymorphism and quantitative traits was investigated in an F2 population of pigs. Association analyses were performed using a statistical model that included genotype, sex, batch and sex by genotype interaction as fixed effects and sire as random effect. The polymorphism was associated with the number of right teats $(p=0.03)$, heart weight $(p=0.04)$, lung weight $(p=0.05)$, carcass length determined by the Brazilian carcass classification method $(p=0.04)$, picnic shoulder weight $(p=0.07)$, jowl weight $(p=0.01), p H 24 \mathrm{~h}$ after slaughtering $(p=0.03)$ and drip loss $(p=0.01)$. Interaction between genotype and sex was observed for six performance traits. The additive effect was significant $(p<0.10)$ for heart weight, jowl weight and $\mathrm{pH} 24 \mathrm{~h}$ after slaughtering. The effect of dominance was significant $(p<0.05)$ for number of right teats, heart weight, carcass length, picnic shoulder weight and $\mathrm{pH} 24 \mathrm{~h}$ after slaughtering. This study shows that the growth hormone gene is a potential candidate for investigating the phenotypic variation of quantitative traits in pigs, and suggests its possible application in breeding programs.
\end{abstract}

Key words: candidate genes, divergent cross, molecular marker, sex x genotype interaction, swine.

Received: June 2, 2005; Accepted: April 4, 2006.

\section{Introduction}

Advances in different areas of animal production (management, nutrition, environment, sanitary control and genetic breeding) have led to improvements in the pig production chain. Genetic breeding of herds have been carried out by selecting animals with high production potential based on their phenotype. One alternative for the selection of the best animals to be used as parents of the next generation is to identify genes or loci controlling economically important traits and to incorporate this information into traditional breeding methods.

In the last few years there have been many important advances in molecular genetics and biotechnology. Pigs represent a good animal model for genetic studies due to their short gestational period, large number of piglets per litter and short generation interval. Most of the markers developed and used by the pig breeding industry have been identified by candidate gene analysis. In these studies, an

Send correspondence to Samuel Rezende Paiva. Embrapa Recursos Genéticos e Biotecnologia, 70770-900 Brasília, DF, Brazil. E-mail: samuel@cenargen.embrapa.br. appropriate population design is important, with the F2 design being the most widely used (Liu, 1998). The mating design for a reference population should determine the relationships between polymorphic markers and traits of interest.

Growth hormone $(\mathrm{GH})$ is involved in the regulation of growth and metabolism of different tissues during anabolic and catabolic processes, it may have a direct or indirect effect on the target tissues. The effects of growth hormone, mediated by insulin-like growth factor I (IGF-I), on muscle and skeletal tissue growth are similar to those of insulin, whereas its direct action on carbohydrate metabolism and lipolysis is antagonistic to that of insulin, once growth hormone, along with cortisol, exerts a synergistic effect on lipolysis and diabetogenesis. Most, if not all the effects of growth hormone on muscle development are mediated by IGF-I, and the functions performed by GH make this hormone a candidate gene for various production traits.

The pig growth hormone gene polymorphism (G316A) was identified by sequencing native Brazilian Piau boars and sows of a commercial line (GenBank accession number DQ339698), corresponding of the parental 
generation of the present study population. This polymorphism is located in the first intron of the gene, $316 \mathrm{bp}$ downstream according to the reference sequence (GenBank accession number M17704) published by Vize and Wells (1987).

The objective of the study described in the present paper was to analyse the G316A polymorphism present in the growth hormone gene sequence using the polymerase chain reaction-restriction fragment length polymorphism (PCRRFLP) method and to determine any statistical associations between the G316A polymorphism and quantitative traits in a segregating $\mathrm{F} 2$ pig population. This polymorphism has not yet been studied in pigs and it is important to uncover its effects on the quantitative traits in this population. An additional goal in our study was to demonstrate the potential for genetic analyses in naturalized Brazilian pigs, which has not yet been properly explored.

\section{Material and Methods}

\section{Experimental population}

The F2 pig population was generated by crossing two native Brazilian Piau boars with 18 commercial sows (Landrace $\mathrm{x}$ Large White $\mathrm{x}$ Pietran) selected for growth rate and backfat thickness. The F1 generation consisted of 106 sows and 134 boars (Band et al., 2005; Carmo et al., 2005). Twelve boars from different litters were randomly selected from the $134 \mathrm{~F} 1$ boars and mated by natural breeding with $54 \mathrm{~F} 1$ sows to produce the $\mathrm{F} 2$ generation. The $\mathrm{F} 2$ generation consisted of approximately 840 offspring divided into five batches according to the season in which they were born. Ten days after birth, the males were castrated.

\section{Phenotypes and DNA extraction}

Sixty days after birth the pigs were transferred to collective pens where they were maintained until 77 days of age and then moved to individual cages to measure feed conversion (feed intake/weight gain), average daily gain and feed intake over 28 days (from 77 to 105 days of age). All measurements were performed on the F2 animals and are presented in Table 1, along with standard errors and the total number of pigs analyzed for each trait.

Around $65 \mathrm{~kg}$ of living weight $(64.71 \pm 0.24)$, the F2 offspring pigs were fasted for $20 \mathrm{~h}$, electrically stunned $(300 \mathrm{~V} / 5 \mathrm{~s})$ and slaughtered at the farm's abattoir and bled by cardiac puncture. Data regarding carcass cut traits were obtained by cooling the right half of each carcass at $4{ }^{\circ} \mathrm{C}$ for $24 \mathrm{~h}$, dissected and analyzed as described by Nascimento and Mota (2000). Loin samples (longissimus dorsi) were removed from the animals for the analysis of meat quality, which was performed at the Meat Laboratory of the Department of Food Technology, Federal University of Viçosa (UFV), Viçosa, Minas Gerais (MG), Brazil. The number of observations, means and standard errors for the analyzed traits are shown in Table 2. All the F2 population results re-
Table 1 - Number of F2 offspring (n) analyzed, mean and standard error (SE) with each performance trait.

\begin{tabular}{|c|c|c|}
\hline Trait $^{1}$ & $\mathrm{n}$ & Mean $\pm \mathrm{SE}$ \\
\hline Total teat number $(\mathrm{TN})$ & 815 & $13.17 \pm 0.05$ \\
\hline Right teat number (RTN) & 815 & $6.62 \pm 0.03$ \\
\hline Left nipple number (LTN) & 816 & $6.62 \pm 0.03$ \\
\hline Birth weight (BW, kg) & 815 & $1.20 \pm 0.01$ \\
\hline Weight at 21 days (W21, kg) & 673 & $4.91 \pm 0.04$ \\
\hline Weight at 42 days (W42, $\mathrm{kg}$ ) & 668 & $8.31 \pm 0.07$ \\
\hline Weight at 63 days (W63, kg) & 660 & $16.35 \pm 0.13$ \\
\hline Weight at 77 days $(\mathrm{W} 77, \mathrm{~kg}$ ) & 616 & $21.45 \pm 0.17$ \\
\hline Weight at 105 days $(\mathrm{W} 105, \mathrm{~kg})$ & 602 & $36.48 \pm 0.26$ \\
\hline Feed intake from 77 to 105 days (FI, $\mathrm{kg}$ ) & 618 & $39.90 \pm 0.32$ \\
\hline $\begin{array}{l}\text { Average daily gain from } 77 \text { to } 105 \text { days } \\
\text { (ADG, } \mathrm{kg} \text { ) }\end{array}$ & 609 & $0.53 \pm 0.01$ \\
\hline $\begin{array}{l}\text { Feed conversion from } 77 \text { to } 105 \text { days } \\
\left(\mathrm{FC} \mathrm{kg} \mathrm{kg}^{-1}\right)\end{array}$ & 603 & $2.79 \pm 0.03$ \\
\hline
\end{tabular}

garding performance, carcass yield and meat quality traits were described by Lopes et al. (2002).

Extraction, manipulation and subsequent analysis of genomic DNA were carried out at the Laboratory of Animal Biotechnology (LABTEC), Department of Animal Science, UFV. Blood samples were collected from parental, F1 and F2 animals by venipuncture of the sinus orbitalis at 77 days of age. Genomic DNA was extracted from blood using phenol:chloroform purification after treatment with proteinase K (Sambrook et al., 1989). The DNA samples were diluted to $25 \mathrm{ng} / \mu \mathrm{L}$ in TE buffer containing $10 \mathrm{mM}$ Tris- $\mathrm{HCl}, \mathrm{pH} 8.0$, and $1 \mathrm{mM}$ EDTA, $\mathrm{pH} 8.0$, and stored at $4{ }^{\circ} \mathrm{C}$. The DNA stock solution (concentrated material) was stored at $-20^{\circ} \mathrm{C}$.

\section{PCR and RFLP analysis}

The primer pair used for the amplification of the growth hormone gene region was designed from the sequence published by Vize and Wells (1987), (GenBank accession number M17704) using Primer 3 software (Rozen and Skaletsky, 2000). The F1 - TTATCCATTAGCAC ATGCCTGCC and R1 - CTGGGGAGCTTACAAACTC CTT primer pair was used for amplification of the fragment containing the G316A polymorphism. This primer pair amplifies a 604-bp fragment comprising the promoter region, first exon and part of the first intron of the growth hormone gene.

Restriction analysis used the $(\mathrm{G} \rightarrow \mathrm{A})$ base substitution mutation at position 316 recognized by the FokI restriction enzyme (Invitrogen Inc.). The specific DNA fragment was amplified by PCR in a MJ Research thermocycler (model PTC-100, Watertown, MA, USA) using a reaction mixture containing 4.0 pmol of each primer, $0.2 \mathrm{mM}$ of each dNTP, $1.0 \mathrm{mM} \mathrm{MgCl} 2,50 \mathrm{mM}$ Tris-KCl, 1.0 unit Taq DNA polymerase and $25 \mathrm{ng}$ of genomic DNA in a final 
volume of $20 \mu \mathrm{L}$. The amplification program consisted of initial denaturation at $94{ }^{\circ} \mathrm{C}$ for $5 \mathrm{~min}$ followed by $35 \mathrm{am}$ plification cycles of strand denaturation at $94{ }^{\circ} \mathrm{C}$ for $1 \mathrm{~min}$, primer annealing at $64^{\circ} \mathrm{C}$ for $1 \mathrm{~min}$ and fragment extension

Table 2 - Number of F2 offspring analyzed (n), mean and standard error (SE) of carcass, carcass cut and meat quality traits.

\begin{tabular}{|c|c|c|}
\hline Trait & $\mathrm{n}$ & Mean \pm se \\
\hline Slaughter weight $(\mathrm{SW}, \mathrm{kg})$ & 529 & $64.71 \pm 0.24$ \\
\hline Slaughter age (SA, days) & 538 & $147.81 \pm 0.43$ \\
\hline Carcass weight $(\mathrm{CW}, \mathrm{kg})$ & 540 & $53.60 \pm 0.23$ \\
\hline Carcass yield $(\mathrm{CY}, \%)$ & 526 & $81.99 \pm 0.09$ \\
\hline Right half carcass weight (RHCW, $\mathrm{kg}$ ) & 839 & $26.84 \pm 0.09$ \\
\hline $\begin{array}{l}\text { Carcass length by the American carcass } \\
\text { classification method (MLC, } \mathrm{cm} \text { ) }\end{array}$ & 540 & $71.67 \pm 0.14$ \\
\hline $\begin{array}{l}\text { Midline backfat thickness at last rib } \\
(\mathrm{LR}, \mathrm{mm})\end{array}$ & 549 & $19.81 \pm 0.21$ \\
\hline $\begin{array}{l}\text { Midline backfat thickness between last } \\
\text { and next to last but one lumbar vertebra } \\
(\mathrm{LL}, \mathrm{mm})\end{array}$ & 547 & $28.51 \pm 0.25$ \\
\hline $\begin{array}{l}\text { Midline backfat thickness above the last } \\
\text { lumbar vertebra (L, } \mathrm{mm})\end{array}$ & 495 & $45.01 \pm 0.09$ \\
\hline $\begin{array}{l}\text { Backfat thickness at last rib, } 6.5 \mathrm{~cm} \\
\text { from the midline }(\mathrm{P} 2, \mathrm{~mm})\end{array}$ & 547 & $16.81 \pm 0.16$ \\
\hline Loin depth $(\mathrm{LD}, \mathrm{mm})$ & 495 & $43.80 \pm 0.20$ \\
\hline Loin eye area (LEA, $\left.\mathrm{cm}^{2}\right)$ & 499 & $26.30 \pm 0.17$ \\
\hline Total ham weight (THW, kg) & 543 & $7.28 \pm 0.04$ \\
\hline $\begin{array}{l}\text { Skinless and fatless ham weight } \\
(\mathrm{HW}, \mathrm{kg})\end{array}$ & 543 & $4.99 \pm 0.03$ \\
\hline $\begin{array}{l}\text { Total Boston shoulder weight } \\
\text { (TBSW, } \mathrm{kg} \text { ) }\end{array}$ & 549 & $2.34 \pm 0.02$ \\
\hline $\begin{array}{l}\text { Skinless and fatless Boston shoulder } \\
\text { weight }(\mathrm{BSW}, \mathrm{kg})\end{array}$ & 544 & $1.69 \pm 0.01$ \\
\hline $\begin{array}{l}\text { Total picnic shoulder weight } \\
\text { (TPSW, kg) }\end{array}$ & 545 & $4.87 \pm 0.03$ \\
\hline $\begin{array}{l}\text { Skinless and fatless picnic shoulder } \\
\text { weight (PSW, } \mathrm{kg} \text { ) }\end{array}$ & 548 & $2.70 \pm 0.02$ \\
\hline Total (bone-in) loin weight (TLW, kg) & 540 & $3.47 \pm 0.02$ \\
\hline Boneless loin weight $(\mathrm{LW}, \mathrm{kg})$ & 542 & $1.02 \pm 0.01$ \\
\hline Bacon weight $(\mathrm{BCW}, \mathrm{kg})$ & 541 & $2.69 \pm 0.02$ \\
\hline Bacon depth (BCD, mm) & 539 & $24.92 \pm 0.29$ \\
\hline Rib weight (RW, kg) & 548 & $1.52 \pm 0.01$ \\
\hline Sirloin weight (SLW, kg) & 546 & $0.22 \pm 0.02$ \\
\hline Small intestine length (SIL, m) & 544 & $18.42 \pm 0.08$ \\
\hline PH 45 min after slaughter (pH45) & 543 & $6.50 \pm 0.01$ \\
\hline PH $24 \mathrm{~h}$ after slaughter $(\mathrm{pHu})$ & 555 & $5.71 \pm 0.01$ \\
\hline Drip loss (DL, \%) & 557 & $3.19 \pm 0.07$ \\
\hline Cooking loss (CL, \%) & 550 & $32.63 \pm 0.11$ \\
\hline Total loss (TL, \%) & 439 & $34.23 \pm 0.13$ \\
\hline Intramuscular fat ( IMF, \%) & 504 & $1.55 \pm 0.03$ \\
\hline Shear force (SF, g per $1.2 \mathrm{~cm})$ & 431 & $5550.63 \pm 42.10$ \\
\hline Redness (A) & 485 & $0.67 \pm 0.03$ \\
\hline Yellowness (B) & 491 & $6.62 \pm 0.02$ \\
\hline Chroma (c) & 429 & $6.70 \pm 0.03$ \\
\hline Hue angle (h) & 416 & $84.07 \pm 0.27$ \\
\hline
\end{tabular}

at $72{ }^{\circ} \mathrm{C}$ for $1 \mathrm{~min}$, followed by a final extension step at $72{ }^{\circ} \mathrm{C}$ for $5 \mathrm{~min}$. The amplified products were loaded in a $8 \%(\mathrm{w} / \mathrm{v})$ polyacrylamide gel, stained with silver nitrate. In each gel was also loaded $1 \mu \mathrm{L}$ of a 1-kb ladder (Invitrogen) as a standard.

After amplification of the region containing the polymorphism, $7 \mu \mathrm{L}$ of the PCR product was digested with about 5 units of the FokI restriction endonuclease in a mixture containing $1.5 \mu \mathrm{L}$ buffer, $0.15 \mu \mathrm{L}$ bovine serum albu$\min (10 \mathrm{mg} / \mathrm{mL})$ and $4.85 \mu \mathrm{L}$ Milli-Q water in a final volume of $15 \mu \mathrm{L}$. The mixture was incubated for $1 \mathrm{~h}$ at $37^{\circ} \mathrm{C}$, followed by inactivation at $65^{\circ} \mathrm{C}$ for $20 \mathrm{~min}$. The digestion product was also visualized on silver-stained $8 \%$ (w/v) polyacrylamide gel.

F1 animals were genotyped by PCR-RFLP to identify the alleles inherited from the parental generation. The mutation was first identified by sequencing, when the polymorphism was confirmed, a total of 402 F2 animals was genotyped.

\section{Statistical analysis}

The database consisted of two basic files, one containing the phenotypic measurements of all evaluated traits in about 600 animals and the other the marker genotypes coded as GG (homozygous wild-type genotype), AA (homozygous G316A mutant genotype) or GA (heterozygous wild-type/mutant genotype). A total of 402 animals were genotyped for the G316A polymorphism. The association between the genotypes and evaluated traits was analyzed statistically using the SAS program (1998) and the following model:

$y_{i j k l m}=\alpha+G_{i}+S_{j}+G S_{i j}+B_{k}+s_{l}+\left(C_{i j k l m}-\bar{C}\right) b+e_{i j k l m}$

where $y_{i j k l m}=$ trait observed in pig m, of genotype $i$, sex $j$, from batch $k$, and sire $1 ; \alpha=$ constant inherent to all observations; $G_{i}=$ fixed effect of genotype $i(i=1,2,3) ; S_{j}=$ fixed effect of sex $j, j=1,2(1=$ castrated males, $2=$ females $)$; $G S_{i j}=$ interaction between genotype $i$ and $\operatorname{sex} j ; B_{k}=$ fixed effect of batch $k, k=1,2,3,4$ and $5 ; s_{l}=$ random effect of sire $1(1=1, \ldots) ; b=$ linear regression coefficient of the $y_{i j k l m}$ trait in relation to the covariable; $C_{i j k l m}=$ value of the covariable observed in animal $m$, of genotype $i$, sex $j$, from batch $k$, and sire $l ; \bar{C}=$ mean value of the covariable; and $e_{i j k l m}=$ random error associated with each observation.

The following covariables were used: litter size at birth for the birth weight trait; litter size at weaning for weight at 21, 42, 63, 77 and 105 days of age and weight at slaughter; weight at 77 days for feed intake, average daily gain and feed conversion; carcass weight for all carcass traits; weight of the cooled right carcass side for cut traits; and age at slaughter for meat quality traits. No covariable was used for the total number of left and right teats.

Covariances between genetic and environmental effects (permanent and temporary) and between environmen- 
tal effects of different animals were considered to be zero. Association analyses were evaluated by the F-test between molecular markers and trait measures and between genotype vs. sex interaction. In both analyses, genotype means were compared by the t-test when the interaction was significant by the F-test.

The additive effect was determined by regression of the values obtained for each genotype compared to the number of non-mutated alleles. The effect of dominance was determined by linear contrasts between genotype means and the t-test was used to evaluate the significance of the dominance effect.

\section{Results}

Digestion of the PCR product and subsequent electrophoresis revealed three genotypes, with genotype GA showing fragments of 604, 345 and $259 \mathrm{bp}$, genotype GG fragments of 345 and $259 \mathrm{bp}$ and genotype AA a single 604-bp fragment (Figure 1). In the parental generation both boars and four sows were heterozygous (GA) for the G316A polymorphism and 14 sows had the wild-type homozygous genotype (GG). A total of 402 F2 offspring were genotyped for the G316A polymorphism. The genotype frequency was $\mathrm{GG}=0.5672$ (228 offsprings), $\mathrm{GA}=0.4005$ (161 offsprings) and $\mathrm{AA}=0.3230$ (13 offspring). The gene frequency for the $\mathrm{G}$ allele was 0.7674 and 0.2326 for the $\mathrm{A}$ allele.

The significance level, mean and standard error, and additive and dominance effects of the genotypes for each significant trait are shown in Table 3 . The G316A polymorphism was found to be associated with the number of right teats, heart weight, lung weight, carcass length measured by the Brazilian carcass classification method, total picnic shoulder weight, jowl weight, $\mathrm{pH} 24 \mathrm{~h}$ after slaughtering (pHu) and drip loss (DL). According to these results, AA animals presented a larger number of teats than the other genotypes. Mean carcass length measured by the Brazilian method was greater in GG and smaller in AA offspring. Mean total picnic shoulder weight was higher in heterozygous offspring compared to the other two genotypes. Re- garding significant meat quality traits ( $\mathrm{pHu}$ and $\mathrm{DL}$ ), AA offspring showed lower $\mathrm{pHu}$ values and a higher DL mean, whereas a lower DL mean was observed for the GG genotype and higher $\mathrm{pHu}$ values were noted in GG and heterozygous offspring.

A significant additive effect of the G316A polymorphism was present for heart weight (HEW), jowl weight (JW) and pHu (Table 3). The absence of a significant dominance effect was only observed for lung weight (LUW), JW and DL.

The genotype (x) sex interaction was significant for some traits in F2 pigs with the polymorphism in the porcine growth hormone $(P G H)$ gene. Figure 2 shows the level of significance of the genotype $\mathrm{x}$ sex interaction and trait means obtained for F2 males and females within each genotype class. For the males, the wild homozygous genotype (GG) was only significantly higher than the other genotypes in regard to the carcass length as measured by the Brazilian carcass classification method (BCL) trait. For the females, the homozygous G316A mutant genotype (AA) was significantly higher in respect to backfat thickness after the last rib $6.5 \mathrm{~cm}$ from the midline (the P2 trait), a trait related to fat deposition.

\section{Discussion}

Three main hypotheses can be postulated to explain the observed association between the change in nucleotides represented by the G316A polymorphism and some quantitative traits. One hypothesis is that the G316A polymorphism is directly responsible for the variation in the observed traits, with this polymorphism being involved in the synthesis of a more or less efficient protein (i.e. PGH) or interfering at various levels of expression such as transcription, processing, transport or the half-life of the circulating hormone. The G316A polymorphism is located at intron I on a non-expressed region of the gene. Although the probability of exerting biological effects on gene expression is higher for polymorphisms located on exonic regions, it is possible that polymorphisms located on unexpressed regions could interfere in gene expression, e.g. polymor-
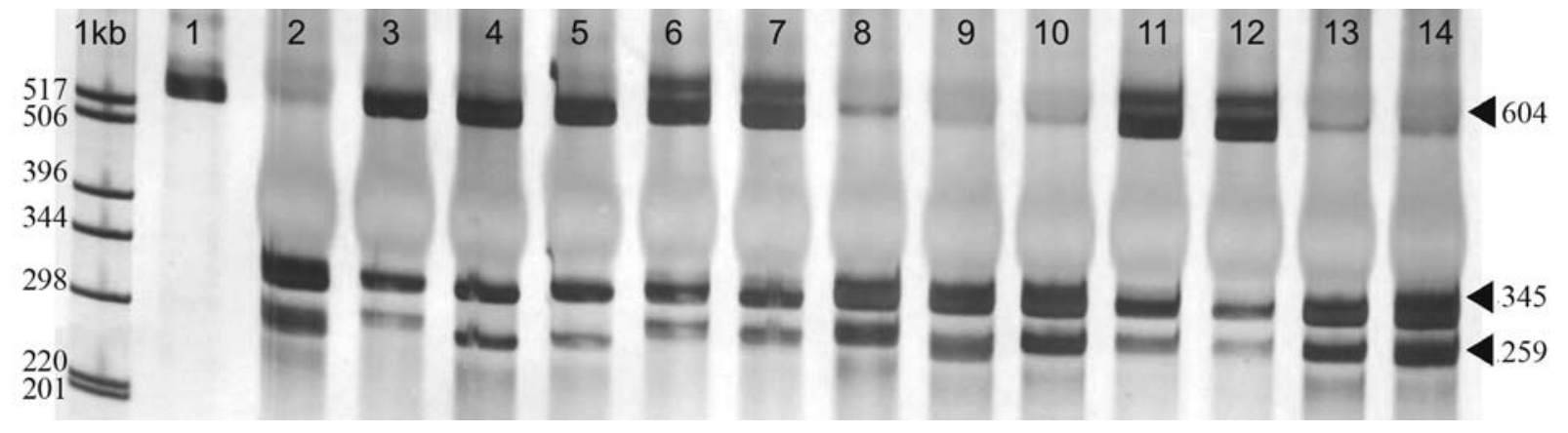

Figure 1 - Example of G316A polymorphism obtained by PCR-RFLP analysis in 8\% polyacrylamide gels using silver staining of material from F2 pigs. Each lane (1-14) represents a separate pig. $1 \mathrm{~kb}=$ DNA Ladder (Invitrogen Inc.). Lane 1 = genotype AA; Lanes 2,8,9,10,13 and 14=genotype GG; Lanes 3-7, 11 and 12 = genotype GA. Arrows represent the size of the PCR-RFLP fragments identified. 

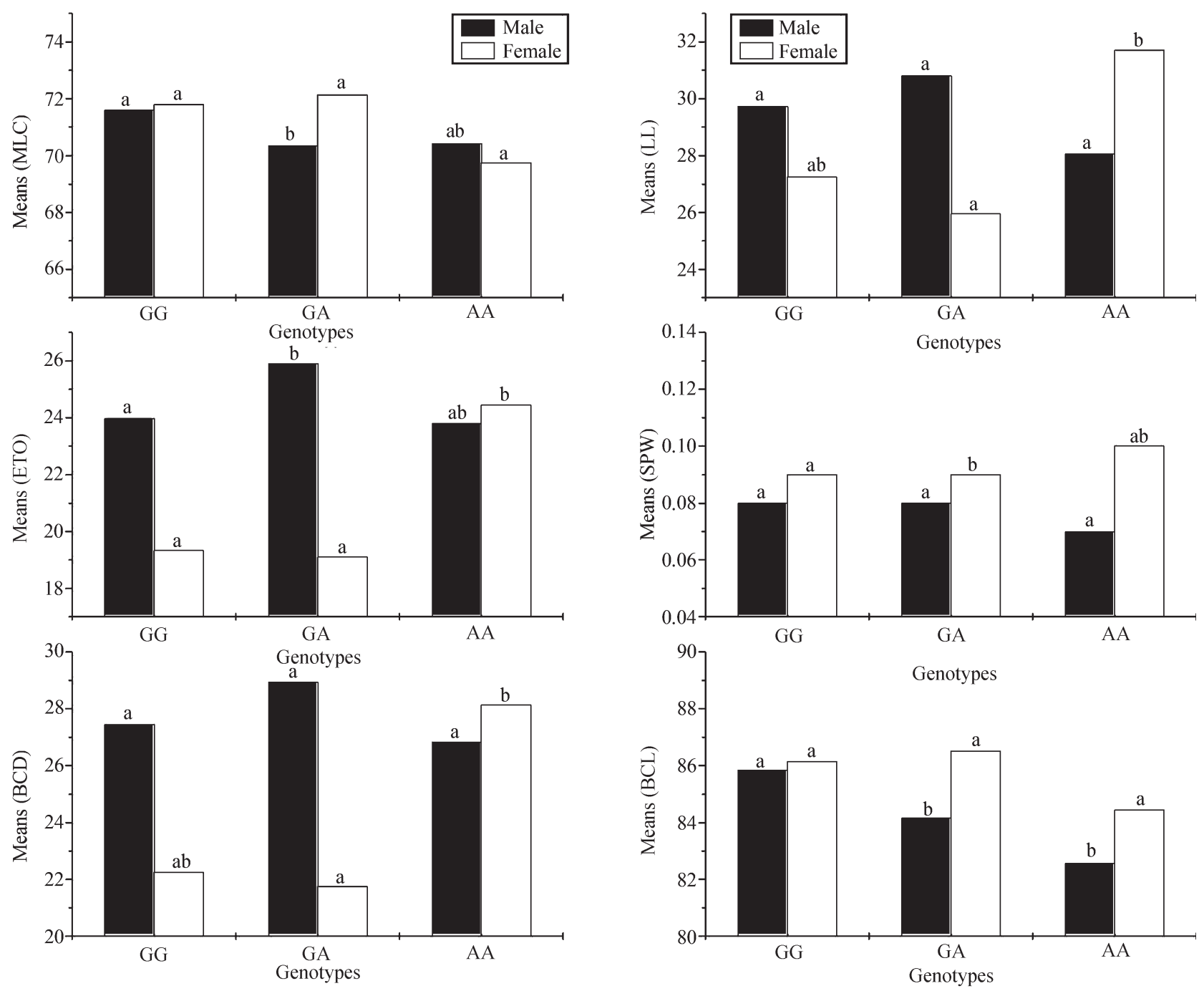

Figure 2 - Variation of trait means obtained for the G316A genotypes within each sex in F2 pigs. For each sex, means followed by the same letter are not significantly different ( $\mathrm{t}$-test, $\mathrm{p}<0.05)$. BCL $=$ carcass length measured by the Brazilian carcass classification method; MLC $=$ carcass length measured by the American carcass classification method; LL = backfat thickness between last and next to last but one lumbar vertebra, at midline; ETO = backfat thickness after last rib, $6.5 \mathrm{~cm}$ from the midline, equivalent to P2; SPW = spleen weight; and $\mathrm{BCD}=$ bacon depth.

phisms located on enhancer regions consisting of coded or uncoded sequences that physically act on the regulation of gene expression.

A second hypothesis is that the polymorphism is in linkage disequilibrium with another polymorphism which is the true causative agent of the observed variations in the analyzed traits. Other important genes that might be associated with production traits are present on pig chromosome 12 (SSC12), e.g. the acetyl CoA carboxylase gene and apolipoprotein $H$ gene. In this case, the polymorphism described on the first intron of the $P G H$ gene would be acting as a marker for the true site, which in turn would explain the associations. This hypothesis could be tested by the analyses of the frequency of these genes in the population described in our present paper.

A third hypothesis is the existence of false-positive associations. The statistical model used by us assumed that only polymorphisms and fixed and random effects influence trait means. However, it is known that phenotypic variation is controlled by many factors, including polygenic and environmental variations. Another fact that could possibly have resulted in false-positive associations is the limited number of observations for genotype AA (0.3230). In order to minimize the effect of this third hypothesis, we applied the same statistical tests excluding genotype AA and the results were the same as those observed when the three genotypes were analyzed, based on which we maintained the AA animals in the analyses.

Other studies have shown the association of PGH with economic traits in swine (e.g., Cheng et al., 2000; Knorr et al., 1997) and the probability of false positives in this study is small so the false-positive hypothesis can probably be discarded, although further studies are necessary to 
Table 3 - Number of F2 offspring anayzed (n), trait means (mean) with standard errors (SE), additive (A) and dominance (D) effects obtained for each genotype of the G316A polymorphism for significant performance, carcass, carcass cut and meat quality traits in F2 pigs.

\begin{tabular}{|c|c|c|c|c|c|c|c|c|c|}
\hline \multirow[b]{2}{*}{ Trait } & \multirow[b]{2}{*}{$\mathrm{F}^{2}$} & \multicolumn{2}{|c|}{ GG genotype } & \multicolumn{2}{|c|}{ GA genotype } & \multicolumn{2}{|c|}{ AA genotype } & \multirow[b]{2}{*}{ A } & \multirow[b]{2}{*}{$\mathrm{D}$} \\
\hline & & $\mathrm{n}$ & $\operatorname{Mean}^{3} \pm$ se & $\mathrm{n}$ & $\operatorname{Mean}^{3} \pm \mathrm{se}$ & $\mathrm{n}$ & $\operatorname{Mean}^{3} \pm$ se & & \\
\hline $\begin{array}{l}\text { Number of right teats } \\
\text { (NRT) }\end{array}$ & 0.03 & 200 & $6.56^{\mathrm{a}} \pm 0.13$ & 143 & $6.74^{\mathrm{b}} \pm 0.14$ & 13 & $6.95^{\mathrm{ab}} \pm 0.41$ & 0.65 & $-0.03 * *$ \\
\hline $\begin{array}{l}\text { Carcass length } \\
(\mathrm{BCL}, \mathrm{cm})^{1}\end{array}$ & 0.04 & 182 & $85.99^{\mathrm{a}} \pm 0.25$ & 135 & $85.33^{\mathrm{ab}} \pm 0.35$ & 9 & $83.49^{b} \pm 1.31$ & -0.22 & $1.18^{* *}$ \\
\hline $\begin{array}{l}\text { Lung weight } \\
\text { (LUW, kg) }\end{array}$ & 0.05 & 180 & $0.45^{\mathrm{a}} \pm 0.01$ & 133 & $0.43^{\mathrm{b}} \pm 0.01$ & 9 & $0.43^{\mathrm{ab}} \pm 0.01$ & -0.014 & -0.02 \\
\hline $\begin{array}{l}\text { Picnic shoulder weight } \\
\text { (PSW, kg) }\end{array}$ & 0.07 & 181 & $4.81^{\mathrm{a}} \pm 0.04$ & 134 & $4.90^{\mathrm{b}} \pm 0.04$ & 9 & $4.76^{\mathrm{ab}} \pm 0.21$ & 0.07 & $0.23 * *$ \\
\hline $\begin{array}{l}\text { Jowl weight } \\
(\mathrm{JW}, \mathrm{kg})\end{array}$ & 0.01 & 183 & $0.71^{\mathrm{a}} \pm 0.01$ & 133 & $0.65^{b} \pm 0.01$ & 9 & $0.64^{\mathrm{ab}} \pm 0.04$ & $-0.03 *$ & -0.05 \\
\hline $\begin{array}{l}\mathrm{pH} 24 \mathrm{~h} \text { after slaughter } \\
(\mathrm{pHu})\end{array}$ & 0.03 & 182 & $5.69^{\mathrm{a}} \pm 0.01$ & 142 & $5.71^{\mathrm{a}} \pm 0.01$ & 10 & $5.38^{b} \pm 0.12$ & $0.04 *$ & $-0.01 * *$ \\
\hline Drip loss DL (\%) & 0.01 & 182 & $2.94^{\mathrm{a}} \pm 0.12$ & 142 & $3.45^{\mathrm{b}} \pm 0.14$ & 10 & $4.17^{b} \pm 0.66$ & 0.19 & -0.021 \\
\hline
\end{tabular}

${ }^{1}$ Measured by the Brazilian carcass classification method.

${ }^{2}$ Probability of statistical significance for $\mathrm{F}$ test.

${ }^{3}$ Means followed by different letters in the same line were different by the t-test $(p<0.05)$.

*Significant by the F-test $(\mathrm{p}<0.10)$.

$* *$ Significant by the t-test $(\mathrm{p}<0.05)$.

confirm which of the remaining hypotheses best explain our results.

Despite the importance for metabolism in general, the effect of the G316A polymorphism on the total variation of traits showing an association was relatively small. No association was observed between allelic variants and performance traits influenced by PGH, such as different feed intake, feed conversion rates or body weights (Table 3 ).

Our finding that the non-mutant homozygous genotype (GG) detected in commercial sows of the parental generation was responsible for greater carcass length means, lower drip loss and higher mean $\mathrm{pH} 24 \mathrm{~h}$ after slaughtering can be explained by the fact that commercial animals have been selected over generations for higher meat production, greater carcass length and greater carcass lean meat yield. However, it does not explain the lower drip loss, since commercial pig breeds tend to show higher drip losses compared to naturalized breeds. According to correlation analyses (data nor shown), pHu and DL are negatively correlated $(-0.13 ; \mathrm{p}<0.01)$, a finding confirmed in our study.

Several studies have associated PGH genotypes with traits of interest in some pig breeds. Knorr et al. (1997) studied crosses between Pietran and Meishan pigs and found allelic variants of PGH to be associated with eight carcass composition traits, all of which were related to fat deposition. In contrast, in our study the genotypes were only associated with fat deposition traits when the effect of sex was included in the analysis, with the genotypes being associated with three backfat thickness measurements (LL, ETO and BCD; Figure 2).
Divergent results, even in comparison to the present study, have been reported in investigations associating quantitative traits and allelic variations in the PGH gene. Cheng et al. (2000), analyzing Duroc, Landrace and TaoYuan pigs found positive associations between quantitative traits and PGH allelic variations only for the Tao-Yuan breed, with allelic variants influencing average daily gain and the efficiency of weight gain.

Another important factor is that studies of candidate genes for trait improvement are normally carried out based on variations in quantitative traits that are influenced by various genes and by the environment. Thus, the associations found in experimental populations should not be extrapolated before being tested and validated in the target population. Therefore, the detection and confirmation of the G316A polymorphism in a commercial population is important, because it affects different traits included in animal breeding programs. One of these traits is meat quality (pHu and DL) which is difficult to measure, by traditional selection methods. One alternative for the selection of these traits is marker-assisted selection using, for example, the genotypes here described.

Sex hormones (estrogen, testosterone, etc.), along with PGH, may influence traits in castrated males and females in different ways. Few correlation studies about the amount of circulating PGH and the sex of the animal, are available; most investigations associate this parameter with age and animal breed. Dubreuil et al. (1987) reported that sex did not influence basal PGH secretion in growing pigs. In our study there was a positive association between 
G316A genotype variation and sex, but since this polymorphism is located on an intron it was not possible confirm wether or not it causes higher or lower PGH secretion in males or females. However, in our study the males have been castrated and would have shown lower testosterone levels than boars.

In our study, a significant dominance effect was observed for many traits (Table 3). It is likely that the lack of significant additive and dominance effects for the drip loss and lung weight traits was a consequence of the fact that in our study only a few pigs had the AA genotype, which might have interfered with the estimates and the significance of the effects. For example, we analyzed drip loss in 9 AA pigs, $142 \mathrm{GA}$ pigs and $182 \mathrm{GG}$ pigs. Thus, these effects should be tested for using larger commercial populations in order to validate any gene effects.

Since parents transfer their genes and not their genotypes to their offspring, the advantage of a direct marker would be that it presents a higher additive than dominance effect, since effects of dominance are caused by the interaction between alleles at the same locus and these interactions are rearranged in each generation. Thus, it is important to know whether any polymorphism effects are due to additive action or to dominance deviation.

Positive associations between allelic variants and breed have been reported in investigations analyzing different breeds. In our study we evaluated a Brazilian naturalized breed with a different origin from that of the breeds used in European and North American studies. However, this was probably not the main reason for the positive associations between genotypes and traits here studied. The described PGH G316A mutation is not exclusive to the Piau breed and has also been detected in commercial females resulting from Landrace x Large White x Pietran crosses, breeds widely used in candidate gene analysis.

Our study demonstrates the potential of the PGH gene as a candidate for the investigation of quantitative traits in pigs and suggests that the G316A polymorphism should be tested in commercial populations for its possible application in marker-assisted selection programs in pigs.

\section{Acknowledgments}

The authors wish to thank the Brazilian agencies FAPEMIG, CNPq and CAPES for financial support and Dr. Luiz L. Coutinho (USP/ESALQ) and Dr. Marta Guimarães (EMBRAPA/Gado de Leite) for help with the gene sequencing and sequence editing.

\section{References}

Band GO, Guimarães SEF, Lopes PS, Peixoto JO, Faria DA, Pires AV, Figueiredo FC, Nascimento CS and Gomide LAM (2005) Relationship between the Porcine Stress Syndrome gene and carcass and performance traits in $\mathrm{F}_{2}$ pigs resulting from divergent crosses. Genet Mol Biol 28:92-96.

Carmo FMS, Guimarães EF, Lopes PS, Pires AV, Guimarães MFM, Silva MVGB, Schierholt AS, Silva KM and Gomide LAM (2005) Association of MYF5 gene allelic variants with production traits in pigs. Genet Mol Biol 28:363-369.

Cheng WTK, Lee CH, Hung CM, Chang TJ and Chen CM (2000) Growth hormone gene polymorphisms and growth performance traits in Duroc, Landrace and Tao-Yuan pigs. Theriogenology 54:1226-1237.

Dubreuil P, Pelletier G, Petitclerc D, Lapierre H, Couture Y, Brazeau P, Gaudreau P and Morisset J (1987) Influence of age and sex on basal secretion of growth hormone $(\mathrm{GH})$ and on GH-induce release by porcine GH-releasing factor $\mathrm{pGRF}$ (1-29 NH2) in growing pigs. Dom Animal Endocri 4:229-307.

Knorr C, Moser G and Geldermann H (1997) Associations of GH gene variants with performance traits in F2 generations of European wild boar, Pietran and Meishan pigs. Anim Genet 28:124-128.

Liu BH (1998) Computational tools for study of complex traits. In: Paterson AH (ed) Molecular Dissection of Complex Traits. CRC Press, Nova York, pp 43-80.

Lopes PS, Guimarães SEF, Pires AV, Soares MAM, Carmo FMS, Martins MF, Benevenuto Júnior AA and Gomide LAM (2002) Results of performance, carcass yield and meat quality traits of F2 crosses between Brazilian native and commercial pigs for QTL mapping. Proceedings of 7th World Congress on Genetics Applied to Livestock Production, Montpellier, pp 155-158.

Nascimento JD and Mota EO (2000) Dissecção de carcaças de suínos na Agroceres PIC. Informe Técnico, AGROCERES PIC, Rio Claro, 5 pp.

Rozen S and Skaletsky HJ (2000) Primer3 on the WWW for general users and for biologist programmers. In: Krawetz S and Misener S (eds) Bioinformatics Methods and Protocols: Methods in Molecular Biology. Humana Press, Totowa, pp 365-386.

Sambrook J, Fritsch EF and Maniatis T (1989) Molecular Cloning: A Laboratory Manual. 2nd edition. Cold Spring Harbor Laboratory, New York, 564 pp.

SAS (1998) Institut Inc. User's Guide. Statistical Analysis System. Cary, NC, USA.

Vize PD and Wells JRE (1987) Isolation and characterization of the porcine growth hormone gene. Gene 55:339-344.

Associate Editor: Pedro Franklin Barbosa 